\section{Inconsistent reports of risk behavior among Brazilian middle school students: National School Based Survey of Adolescent Health (PeNSE 2009/2012)}

\author{
Inconsistências no relato de comportamentos \\ de risco entre estudantes brasileiros: Pesquisa \\ Nacional de Saúde do Adolescente (PeNSE \\ 2009/2012)
}

Informes inconsistentes de comportamientos de riesgo entre los estudiantes de secundaria de Brasil: Encuesta Nacional de Salud del Adolescente (PeNSE 2009/2012)

\author{
Dandara de Oliveira Ramos 1 \\ Martin Daly 2 \\ Maria Lucia Seidl-de-Moura 3 \\ Rafael Tavares Jomar 1 \\ Paulo Nadanovsky 1
}

\begin{abstract}
This study assessed the consistency of self-reports of risk behavior (overall and within four specific domains: alcohol use, tobacco use, drug use, and sexual activity) in two editions of the Brazilian National School Based Survey of Adolescent Health (PeNSE): 2009 and 2012. The overall proportion of cases with at least one inconsistent response in the two editions was 11.7\% (2.7\% on the alcohol items, 2.1\% for drug use, 4.3\% for cigarette use, 3\% for sexual activity) and 22.7\% (12.8\% on alcohol items, 2.5\% for drug use, 4.3\% for cigarette use, $4.1 \%$ for sexual activity), respectively. Such inconsistency was more prevalent among males, delayed students, those who reported having experimented with drugs, and those who did not have a cellphone. Because inconsistent responses were more prevalent among the students who claimed to have engaged in risky activities, removing inconsistent responders affected the estimated prevalence of all risk behaviors in both editions of the survey. This study supports the importance of performing consistency checks of selfreport surveys, following the growing body of literature on this topic.
\end{abstract}

Risk-Taking; Self Report; Surveys; Methodology; Adolescent

\author{
Correspondence \\ D. O. Ramos \\ Departamento de Epidemiologia, Instituto de Medicina Social, \\ Universidade do Estado do Rio de Janeiro. \\ Rua São Francisco Xavier 524, 7o andar, bloco D, \\ Rio de Janeiro, RJ 20550-990, Brasil. \\ dandararamos2@gmail.com \\ 1 Instituto de Medicina Social, Universidade do Estado do Rio de \\ Janeiro, Rio de Janeiro, Brasil. \\ 2 McMaster University, Hamilton, Canada. \\ 3 Instituto de Psicologia, Universidade do Estado do Rio de \\ Janeiro, Rio de Janeiro, Brasil.
}




\section{Introduction}

The most widely reported measures of youth risk behavior are items from self-report surveys administered in schools 1 . Results from such surveys are commonly used for developing public policy, identifying problem behaviors within a particular school or district, and planning and evaluating prevention activities.

In Brazil, monitoring adolescents' health and risk factors has been an ongoing priority of the National School Based Survey of Adolescent Health 2,3, also known as the PeNSE survey (PeNSE - Pesquisa Nacional de Saúde do Escolar). In the past two decades, as concern about youth health in Brazil has risen, so has the reliance on this survey's data for identifying risks and temporal trends, and for making policy decisions, especially by epidemiologists interested in identifying the prevalence of health risk behaviors and their associated factors 4,5,6,7,8,9,10,11,12,13,14,15,16. There is a growing body of evidence about the validity of such self-reported survey data, indicating that (especially for surveys with young samples) estimates of the prevalence of various activities can sometimes be dramatically over, or underestimated 17,18. The relative validity of dietary 19 and physical activity indicators 20 from the PeNSE questionnaire, as well as its sensitivity, specificity, and correct classification rate have been previously studied. Nevertheless, the data concerning adolescent risk behaviors from the PeNSE survey have apparently never been scrutinized for consistency.

The primary purpose of this study was to examine the consistency of self-reports of risk behavior, overall and within four specific domains: alcohol use, tobacco use, drug use, and sexual activity. A second purpose was to compare the two editions of the PeNSE survey, those of 2009 and 2012, with respect to methodology and sociodemographic aspects of the two years' sample, to document changes in the inconsistency rates between the two and explore possible causes of those changes. A third purpose was to assess how deleting inconsistent, self-contradictory responses would affect prevalence estimates.

\section{Self-reported measures of risk behavior in survey data: quality issues and concerns}

Research on the reliability and validity of self-report has been conducted since the 1940s, but for self-reports of risk behavior, the studies did not begin until the 1980s 21,22,23 and for epidemiologists, interest began a bit later 24 .

Because risk behaviors are often socially disapproved, one concern is that the young respondents may underreport actual behavior, despite the guaranteed anonymity of their responses. As discussed by Barnea et al. 25, this may happen because of fear of admitting use of illegal substances, or because certain actions are considered shameful. Conversely, some adolescents may "brag" or over-report engaging in disapproved or risky behaviors, perhaps as a result of their desire to conform to the presumed norms of their peers 1,26,27,28,29.

In addition to verifying these problems of distorted self-presentation, previous research on selfreport indicates other sources of error. Studies have shown that the individuals often fail to judge the frequencies accurately 23,30,31,32,33,34, and that the extent of error associated with the report of frequency of past behaviors varies intensely among studies. Blair \& Button 30 have established three factors that can affect the accuracy of self-reported frequency of past behaviors: the actual frequency of the event (more frequent behaviors are often reported by using estimation methods, rather than on the basis of actual episodic memory), the question wording (the use of "how many times" induces more inaccuracy than the use of "how many"), and the reference time frame (longer time frames increasing the chance of error). More recent research has shown that holding these three factors constant could help improve the accuracy of self-report data 32,35,36.

Sometimes, the validity of self-reported risk behavior can be assessed by collecting additional, potentially contradictory responses and complementary evidence such as biochemical markers, collateral informant reports and medical interview. Studies of how the validity of self-report can affect the prevalence estimates of risk behaviors (especially for the age at first use of alcohol and drugs) have been intensely developed by epidemiologists and other health sciences researchers, with both community-based and school-based samples 37,38,39,40,41,42,43,44,45. Cross \& Newman-Gonchar 17 have shown that the estimated prevalence of risk behaviors, antisocial behaviors, and victimization experi- 
ences were substantially reduced when the respondents who gave multiple inconsistent, or extreme responses to other survey items were screened out of the data.

Inaccurate measures of risk behavior not only bias prevalence estimates, but can also act as confounders for the study of morbidity, mortality, and the social and economic outcomes associated with risk behavior, especially for young samples. As the uncritical acceptance of findings from adolescent surveys can lead to erroneous conclusions, our aim is to analyze the consistency of self-reports of risk behavior on the 2009 and 2012 PeNSE surveys, some of the most commonly used data sources about adolescent health in Brazil.

\section{Methods}

\section{Data sources and measures}

The PeNSE is an ongoing school-based survey, conducted by the Brazilian Ministry of Health, together with the Brazilian Institute of Geography and Statistics (IBGE), to monitor the health of children and adolescents enrolled in the 9th grade, from public and private schools. In 2009, a sample consisting of 62,910 students from 6,780 schools was drawn in such a way as to be representative of the student population of Brazil's 26 state capitals plus the Federal District. In 2012, the sample was expanded to be representative of Brazil's five regions, now including rural and urban areas of the South, Southeast, North, Northeast, Central and also the 26 state capitals and the Federal District, comprising a total of 109,104 students, from 2,842 schools 2,3.

In both 2009 and 2012, all students in the selected classrooms who were present on the day of data collection were invited to participate. In 2009, out of the 63,411 students who were present in the classroom, 501 refused to participate $(0.8 \%$ ) and in 2012, from the total of 110,873 students invited, 1,651 refused to participate (1.5\%). The 9th grade was chosen because the students in this grade, mostly aged between 13 and 15 years old, have already acquired the necessary skills to answer self-applicable questionnaires. Other reasons for the choice of 9 th grade were because this group is prone to being exposed to several risk factors, and to permit comparability with various survey systems from other countries 46,47 .

The students answered the questionnaire using a personal digital assistant palmtop, similar to a smartphone. The 2009 questionnaire had 104 questions, involving items about socioeconomic status, social support, bullying, nutritional habits, body image perception, oral health, physical activity, substance use (alcohol, drugs and cigarettes), sexual activity, safety, accidents, and exposure to violence. In 2009, anthropometric measures were collected by the survey team for all the students.

In 2012, questions about asthma, hygiene habits, mental health, work activity, and use of health services were added, summing to a total of 127 questions. Some of the questions from 2009 were altered, and anthropometric measures were not collected in 2012. For further details, see the documentation of the 2009 and 2012 PeNSE survey 2,3.

\section{Analytical approach}

In order to detect inconsistent responses, we created indicator variables for each behavior (called "flag variables"), which took on the value of 1 if a response was logically inconsistent with a previous statement about having ever engaged in that specific behavior. Using these domain-specific indicators of inconsistency, we then created a variable representing the total number of inconsistent responses given by each participant (2009's range $=0-19,2012$ 's range $=0-23$ ). We also used these indicators to calculate the domain-specific and overall inconsistency rates.

Examples of inconsistencies found in the data included logical forms, such as a report of past use of alcohol at one period, followed by a report of never having drunk alcohol on a subsequent question. The opposite pattern of inconsistency was also considered, where participants who answered "yes" to the "have you ever" question then claimed to have never engaged in that behavior in a subsequent answer. Responses were also flagged as inconsistent when the participant reported a particular age at which he had first engaged in a behavior which was above his current reported age. A list of the 
questions inspected for inconsistencies in the 2009 and 2012 editions of the PeNSE survey can be found in Table 1.

In order to explore the patterns of inconsistent responding and identify factors that might account for them, we conducted three types of analyses. First, we determined the rates of inconsistent responses among the participants in 2009 and 2012 for each type of behavior (sexual activity, alcohol, cigarettes and drug use), and across all of the questions.

Second, we calculated the prevalence of alcohol, drug and cigarette use, and sexual activity, after cleaning the data of all the cases with inconsistent responses on these domains, and then compared the results with the prevalences reported in previous studies based on the data from the 2009 4,9,13,14,15 and 2012 6,8,10,12,16 editions of the PeNSE survey.

Third, we estimated a logistic regression model, to measure the relationship between giving an inconsistent response, and various participant characteristics: age (categorized according to norms for the 9th grade in Brazil 47 as"age appropriate" - ages 13 to 16, "accelerated" - ages 11 or 12, or "delayed” - ages 17 to 19), sex, type of school (private or public), possession of a cellphone, self-report of drug use, and self-reported level of difficulty in answering the questionnaire. As there are strong socioeconomic 48,49 and cultural differences 50,51,52 in risk attitudes across Brazil's five regions, we have also included regional dummies as potential"explanatory" variables.

\section{Results}

In 2009, $11.7 \%$ of the participants provided inconsistent responses for at least 1 of the 19 questions about risk behavior. In 2012, this percentage increased, with $22.7 \%$ of the participants giving an inconsistent response for at least 1 of the 23 questions. Limiting the analysis only to the identical questions in both surveys (19 items), the 2012 edition still showed an inconsistency rate of $22.2 \%$. Table 2 shows the percentage of the participants providing at least one inconsistent response across all items, and for each of the four domains.

Inconsistency rates were higher for the most common behaviors: alcohol (2.7\% in 2009 and $12.8 \%$ in 2012) and cigarettes (4.3\% in 2009 and 2012). It is noteworthy that, in 2012, the question "How old were you when you had your first dose of alcohol?" was alone responsible for $46.6 \%$ of all the inconsistencies, but in 2009, inconsistencies on this question constituted only $10.2 \%$ of the total.

Only $1.3 \%$ of the participants in 2009 , and $3.4 \%$ of the participants in 2012, were flagged in more than two domains. Inconsistency in one domain was not strongly associated with inconsistency in the others. Most inconsistent responders provided an inconsistent response in only one of the four domains (89.9\% in 2009, and $89.1 \%$ in 2012).

To analyze how these inconsistency rates may have affected the prevalence estimates of risk behavior which have been published previously on the basis of only the "have you ever" questions $6,7,8,9,10,12,13,14,15,16$, we calculated the percentage of inconsistent responders in relation to "yes" or "no" responses to those "have you ever" questions. In both 2009 and 2012, there was a higher percentage of self-contradiction among the participants who said yes than among those who said no, except for alcohol experimentation. Table 3 shows the percentage of inconsistent responders in both cases. For example, $8 \%$ of the participants in 2009 , and $9.6 \%$ in 2012 , claimed to have experimented with drugs, but $23.1 \%$ of the $8 \%$ (in 2009) and $31.7 \%$ of the $9.6 \%$ (in 2012) did not corroborate those positive responses on subsequent questions about the frequency, or age at first use.

As shown in Table 4, the removal of inconsistent responders affects the estimated prevalence of these risk behaviors in different directions, and with different magnitudes.

Next, we examined the participant characteristics, and socio-demographic aspects of the sample, to determine which variables were significantly associated with giving an inconsistent response in at least one item. Table 5 shows the results from the final adjusted logistic regression model, as well as the unadjusted coefficients (univariate regression), and the percentages of inconsistencies within each of the independent variables.

Males were significantly more inconsistent than females in their responses, especially in the domain of sexual activity, where males constituted $64.7 \%$ of the inconsistent responders in 2009 and $63.1 \%$ in 2012. 
Table 1

Inconsistency rates on each question for the 2009 and 2012 data.

\begin{tabular}{|c|c|c|c|}
\hline Questions & Response alternatives & $\begin{array}{l}2009 \\
\text { n (\%) }\end{array}$ & $\begin{array}{l}2012 \\
\text { n (\%) }\end{array}$ \\
\hline Have you ever had sex? & Yes or No & & \\
\hline How old were you when you had sex for the first time? & $\begin{array}{l}\text { I never had sex; } 9 \text { years or younger; } 10 ; 11 ; 12 ; \\
\qquad 13 ; 14 ; 15 ; 16 \text { or older }\end{array}$ & $478(0.8)$ & $1,104(1.0)$ \\
\hline In life, with how many people have you had sex? & $\begin{array}{c}\text { I never had sex; } 1 ; 2 ; 3 ; 4 ; 5 ; 6 \text { or more; I don't } \\
\text { remember * }\end{array}$ & $552(0.9)$ & $1,367(1.3)$ \\
\hline Have you had sex in the last 12 months? & Yes or No & $547(0.9)$ & $1,367(1.3)$ \\
\hline $\begin{array}{l}\text { In the last time you had sex, did you or your partner use } \\
\text { a condom? }\end{array}$ & I never had sex; Yes; No; I don't know & $778(1.3)$ & $1,837(1.7)$ \\
\hline $\begin{array}{l}\text { In the last time you had sex, did you or your partner use any } \\
\text { contraceptive method (other than condoms)? }\end{array}$ & I never had sex; Yes; No; I don't know & $856(1.4)$ & $1,720(1.6)$ \\
\hline $\begin{array}{l}\text { In the last time you had sex, did you or your partner use any } \\
\text { method for STD prevention? ** }\end{array}$ & I never had sex; Yes; No; I don't know & - & $1,834(1.7)$ \\
\hline $\begin{array}{l}\text { Have you ever tried drugs (marijuana, cocaine, crack, cola, lolól } \\
\text { lança-perfume (ether inhalants), ecstasy, oxy, etc)? }\end{array}$ & Yes or No & & \\
\hline $\begin{array}{l}\text { How many times have you used drugs such as marijuana, cocaine, } \\
\text { crack, cola, lolóllança-perfume, or ecstasy in the last } 30 \text { days? }\end{array}$ & $\begin{array}{c}\text { None in the last } 30 \text { days; One or two times, Three } \\
\text { to five times; Six to nine times; More than } 10 \\
\text { times }\end{array}$ & $126(0.2)$ & $2,241(2.1)$ \\
\hline How old were you when you first tried drugs? & $\begin{array}{l}\text { I have never used drugs; } 9 \text { years or younger; } 10 \\
\qquad 11 ; 12 ; 13 ; 14 ; 15 ; 16 ; 17 \text { or older } * * *\end{array}$ & $1,284(2.1)$ & $2,501(2.3)$ \\
\hline How many times have you used marijuana in the last 30 days? ** & $\begin{array}{c}\text { None in the last } 30 \text { days; One or two times, Three } \\
\text { to nine times; More than } 10 \text { times }\end{array}$ & - & $118(1.3)$ \\
\hline How many times have you used crack in the last 30 days? ** & $\begin{array}{l}\text { None in the last } 30 \text { days; One or two times, Three } \\
\text { to nine times; More than } 10 \text { times }\end{array}$ & - & $67(0.7)$ \\
\hline Have you ever tried alcohol? & Yes or No & & \\
\hline $\begin{array}{l}\text { Have you ever consumed a whole dose of alcohol in your life? } \\
\text { (a dose is equivalent to a can of beer, a glass of wine, a shot of } \\
\text { cachaça or whiskey, etc) ** }\end{array}$ & Yes or No & - & $2,381(2.2)$ \\
\hline How old were you when you first tried alcohol? \# & $\begin{array}{l}\text { I never tried alcohol; Seven years or younger; } \\
\text { Eight to nine years; } 10 \text { to } 11 \text { years; } 12 \text { to } 13 \text { years; } \\
\qquad 14 \text { to } 15 \text { years; } 16 \text { years or older }\end{array}$ & $734(1.2)$ & $11,532(10.6)$ \\
\hline $\begin{array}{l}\text { In the last } 30 \text { days, on the days you had alcohol, how many glasses } \\
\text { or doses did you have? }\end{array}$ & $\begin{array}{l}\text { I did not drink in the last } 30 \text { days; Less than a } \\
\text { glass or a dose; One glass or dose; Two glasses } \\
\text { or doses; Three; four; five or more }\end{array}$ & $106(0.2)$ & $537(0.5)$ \\
\hline $\begin{array}{l}\text { In the last } 30 \text { days, how many days you had a glass or a dose of } \\
\text { alcohol? (a dose is equivalent to a can of beer, a glass of wine, a } \\
\text { shot of cachaça or whiskey, etc.) }\end{array}$ & $\begin{array}{l}\text { None in the last } 30 \text { days; One to two days; Three } \\
\text { to five days; Six to Nine days; } 10 \text { to } 19 \text { days; } 20 \text { to } \\
29 \text { days; Every day in the last } 30 \text { days }\end{array}$ & $110(0.2)$ & $581(0.5)$ \\
\hline In the last 30 days, where did you get/bought your drinks? & $\begin{array}{l}\text { I did not drink in the last } 30 \text { days; In a } \\
\text { supermarket, store, bar or grocery store; From a } \\
\text { street seller (camelô); I gave money to someone } \\
\text { else to buy for me; From a friend; At home; At a } \\
\text { party; Any other way }\end{array}$ & $120(0.2)$ & $721(0.7)$ \\
\hline In your life, how many times have you got drunk? & $\begin{array}{l}\text { Never; One to two times; Three to five; Six to } \\
\text { nine; } 10 \text { or more times }\end{array}$ & $146(0.2)$ & $433(0.4)$ \\
\hline
\end{tabular}

(continues) 
Table 1 (continued)

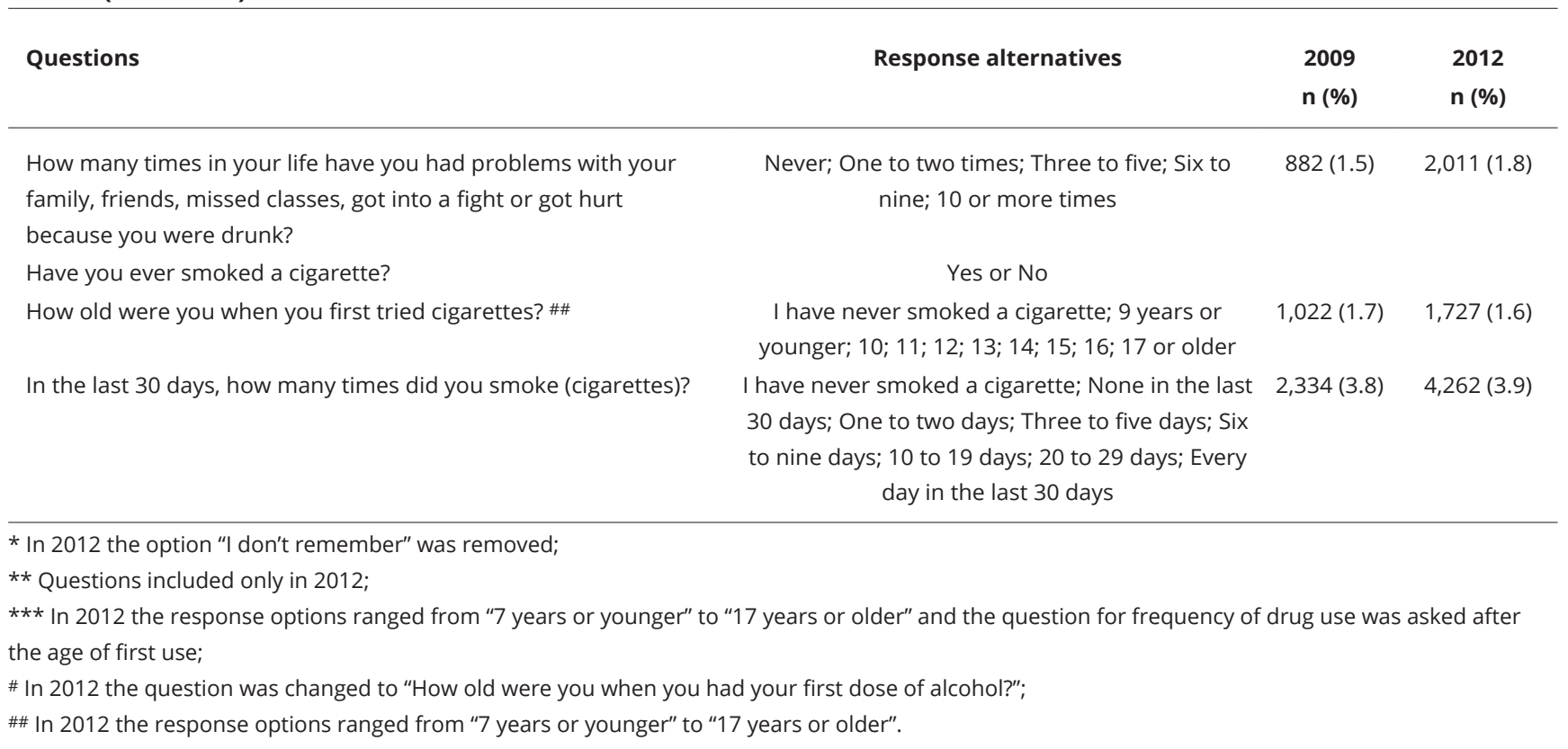

\section{Table 2}

Inconsistency rates by domain and for at least one item across all domains (2009, N =62,910; 2012, N = 109,104).

\begin{tabular}{lcc}
\hline Risk behavior domain & $\begin{array}{c}\mathbf{2 0 0 9} \\
\mathbf{n}(\%)\end{array}$ & $\begin{array}{c}\mathbf{2 0 1 2} \\
\mathbf{n}(\%)\end{array}$ \\
\hline Alcohol & $1,714(2.7)$ & $13,977(12.8)$ \\
Drug use & $1,335(2.1)$ & $2,700(2.5)$ \\
Cigarette use & $2,733(4.3)$ & $4,729(4.3)$ \\
Sexual activity & $1,888(3.0)$ & $4,473(4.1)$ \\
Overall & $7,429(11.7)$ & $24,769(22.7)$ \\
\hline
\end{tabular}

Table 3

Percentages of inconsistencies among the "positives" and "negatives" for each domain.

\begin{tabular}{|c|c|c|c|c|}
\hline \multirow[t]{3}{*}{ Have you ever... } & \multicolumn{2}{|c|}{2009} & \multicolumn{2}{|c|}{2012} \\
\hline & Yes & No & Yes & No \\
\hline & Inconsistent responders (\%) & Inconsistent responders (\%) & Inconsistent responders (\%) & Inconsistent responders (\%) \\
\hline Alcohol & 1.5 & 6.6 & 14.0 & 13.8 \\
\hline Tobacco & 16.1 & 0.9 & 17.0 & 1.5 \\
\hline Drugs & 23.1 & 0.4 & 31.7 & 0.3 \\
\hline Sex & 5.6 & 2.9 & 7.5 & 4.0 \\
\hline
\end{tabular}


Comparative table of the prevalence of risk behaviors before and after removing cases with inconsistency within each domain and with at least one inconsistent response in any domain.

\begin{tabular}{|c|c|c|c|c|c|c|}
\hline & \multicolumn{3}{|c|}{2009} & \multicolumn{3}{|c|}{2012 (State capitals) } \\
\hline & Before & $\begin{array}{l}\text { Domain } \\
\text { inconsistencies } \\
\text { removed }\end{array}$ & $\begin{array}{l}\text { All inconsistent } \\
\text { cases removed }\end{array}$ & Before & $\begin{array}{c}\text { Domain } \\
\text { inconsistencies } \\
\text { removed }\end{array}$ & $\begin{array}{l}\text { All inconsistent } \\
\text { cases removed }\end{array}$ \\
\hline & $\%(95 \% \mathrm{Cl})$ & $\%(95 \% \mathrm{Cl})$ & $\%(95 \% \mathrm{Cl})$ & $\%(95 \% \mathrm{Cl})$ & $\%(95 \% \mathrm{Cl})$ & $\%(95 \% \mathrm{Cl})$ \\
\hline \multicolumn{7}{|l|}{ Alcohol } \\
\hline Having experimented & $69.1(69.0-69.2)$ & $70.2(69.8-70.6)$ & $69.4(69.3-69.5)$ & 70.5 (70.4-70.6) & $70.3(70.2-70.4)$ & $69.0(68.9-69.1)$ \\
\hline Regular consumption & $25.6(25.5-25.7)$ & $26.0(25.6-26.3)$ & $25.4(25.3-25.5)$ & $26.8(26.7-26-9)$ & $30.0(29.9-30.1)$ & $29.1(29.0-29.2)$ \\
\hline Drunkenness in lifetime & $21.9(21.8-22.0)$ & $22.1(21.8-22.4)$ & $21.3(21.2-21.4)$ & $24.3(24.2-24.4)$ & $27.1(27.0-27.2)$ & $26.1(26.0-26.1)$ \\
\hline Problems with alcohol & $9.6(9.5-9.7)$ & $8.3(8.1-8.5)$ & $7.9(7.8-8.0)$ & $10.3(10.2-10.4)$ & $9.4(9.3-9.5)$ & $9.0(8.9-9.1)$ \\
\hline \multicolumn{7}{|l|}{ Drugs } \\
\hline Having experimented & $8.0(7.9-8.1)$ & $6.3(6.1-6.5)$ & $6.3(6.2-6.4)$ & $9.6(9.5-9.7)$ & $7.7(7.6-7.8)$ & $8.4(8.3-8.5)$ \\
\hline \multicolumn{7}{|l|}{ Tobacco } \\
\hline Having experimented & $23.4(23.3-23.5)$ & $20.5(20.2-20.8)$ & $20.6(20.5-20.6)$ & $22.3(22.2-22.4)$ & $19.7(19.6-19.8)$ & $21.5(21.4-21.6)$ \\
\hline Current smokers & $20.1(20.0-20.2)$ & $20.6(20.5-20.6)$ & $20.7(20.6-20.8)$ & $19.6(19.5-19.7)$ & $19.7(19.6-19.8)$ & $21.5(21.4-21.6)$ \\
\hline \multicolumn{7}{|l|}{ Sex } \\
\hline Ever had sex & $28.5(28.4-28.6)$ & $28.0(27.6-28.4)$ & $27.1(27.0-27.2)$ & $30.8(30.7-30.9)$ & $30.0(29.9-30.1)$ & $31.3(31.2-31.4)$ \\
\hline $\begin{array}{l}\text { Used a condom at last } \\
\text { sexual intercourse }\end{array}$ & $74.3(74.2-74.4)$ & 76.0 (75.7-76.3) & 76.4 (76.3-76.5) & 73.6 (73.5-73.7) & 75.2 (75.1-75.3) & 75.5 (75.4-75.6) \\
\hline $\begin{array}{l}\text { Used any other } \\
\text { contraceptive method }\end{array}$ & $73.3(73.2-73.4)$ & 75.2 (74.9-75.5) & 75.7 (75.6-75.8) & $74.6(74.5-74.7)$ & 76.9 (76.8-77.0) & 77.1 (77.0-77.2) \\
\hline \multicolumn{7}{|l|}{$\begin{array}{l}\text { Self-reported age of sexual } \\
\text { initiation (years) }\end{array}$} \\
\hline 9 or younger & $7.5(7.4-7.6)$ & $7.6(7.4-7.8)$ & $7.5(7.4-7.6)$ & $6.6(6.5-6.7)$ & $6.5(6.4-6.6)$ & $6.4(6.3-6.5)$ \\
\hline 10 & $5.0(4.9-5.1)$ & $5.1(4.9-5.3)$ & $5.0(4.9-5.1)$ & $4.1(4.0-4.2)$ & $4.1(4.0-4.2)$ & $4.0(3.9-4.1)$ \\
\hline 11 & $5.8(5.7-5.9)$ & $5.9(5.7-6.1)$ & $5.9(5.8-6.0)$ & $5.0(4.9-5.1)$ & $5.3(5.2-5.4)$ & $5.2(5.1-5.3)$ \\
\hline 12 & $13.4(13.3-13.5)$ & 13.9 (13.6-14.2) & $13.9(13.8-14.0)$ & $12.4(12.3-12.5)$ & $13.0(12.9-13.1)$ & $13.1(13.0-13.2)$ \\
\hline 13 & $24.5(24.4-24.6)$ & $25.5(25.1-25.8)$ & $25.9(25.8-26.0)$ & $26.9(26.8-27.0)$ & $28.2(28.1-28.3)$ & $28.7(28.6-28.8)$ \\
\hline 14 & $25.5(25.4-25.6)$ & $26.4(26.0-26.8)$ & $26.6(26.5-26.7)$ & $27.3(27.2-27.4)$ & $28.4(28.3-28.5)$ & $28.9(28.8-29.0)$ \\
\hline 15 & $12.2(12.1-12.2)$ & $12.6(12.3-12.9)$ & 12.5 (12.4-12.6) & $11.5(11.4-11.6)$ & $12.0(11.9-12.1)$ & $11.5(11.4-11.6)$ \\
\hline 16 or older & $4.8(4.7-4.9)$ & $2.9(2.8-3.0)$ & $2.6(2.5-2.7)$ & $4.7(4.6-4.8)$ & $2.5(2.4-2.6)$ & $2.2(2.1-2.3)$ \\
\hline
\end{tabular}

95\% Cl: 95\% confidence interval.

Participants who were delayed for the 9 th grade had a higher rate of inconsistency than ageappropriate participants. In 2009, age-delayed participants were two times more inconsistent than age-appropriate respondents (95\%CI: 1.96-2.39), and, in 2012, their odds of giving an inconsistent response were 1.13 times higher. Being accelerated (more than two years younger than the expected age for the 9th grade) was not significantly associated with giving an inconsistent response.

As previous studies have shown that drug users are more prone to being inconsistent responders, we tested this association in the PeNSE data. Our results showed a strong association between selfreport of having experimented with drugs and inconsistent responding. In 2009, these participants were almost four times more likely to be inconsistent than the participants who did not report having ever experimented with drugs ( $\mathrm{OR}=3.97$; 95\%CI: 3.71-4.24), an association that decreased in 2012, but remained strongly significant (OR $=2.50$; 95\%CI: 2.48-2.52). Excluding the inconsistent cases from the explanatory variable (self-report of drug use) self-report of drug use was no longer a significant predictor of inconsistency in the 2009 data (OR $=1.11$; 95\%CI: 0.99-1.25), but remained significant for 2012. In this case, even when limiting the analysis only to the consistent responders, those who reported having experimented with drugs were significantly more inconsistent than those who have not $(\mathrm{OR}=2.07$; 95\%CI: $1.91-2.25)$. 


\section{Table 5}

Percentage of inconsistent responses, unadjusted and adjusted analysis of the prevalence of inconsistent responses in at least one item by sex, age, having a cellphone, self-reported drug use, self-reported level of difficulty in answering the questionnaire, type of school (private or public) and region.

\begin{tabular}{|c|c|c|c|c|c|c|}
\hline & \multicolumn{3}{|c|}{2009} & \multicolumn{3}{|c|}{2012} \\
\hline & $\%$ & $\begin{array}{l}\text { Unadjusted analysis } \\
\text { OR }(95 \% \mathrm{Cl})\end{array}$ & $\begin{array}{c}\text { Adjusted analysis } \\
\text { OR }(95 \% \mathrm{Cl})\end{array}$ & $\%$ & $\begin{array}{l}\text { Unadjusted analysis } \\
\text { OR }(95 \% \mathrm{Cl})\end{array}$ & $\begin{array}{c}\text { Adjusted analysis } \\
\text { OR }(95 \% \mathrm{Cl})\end{array}$ \\
\hline \multicolumn{7}{|l|}{ Sex } \\
\hline Female & 9.8 & - & - & 20.9 & - & - \\
\hline Male & 14.0 & $1.49(1.42-1.57)$ & $1.40(1.33-1.48)$ & 24.7 & $1.27(1.26-1.28)$ & $1.25(1.24-1.26)$ \\
\hline \multicolumn{7}{|l|}{ Age (years) } \\
\hline Appropriated (13-16) & 11.4 & - & - & 22.7 & - & - \\
\hline Accelarated (11-12) & 10.7 & $0.93(0.73-1.19)$ & $1.02(0.78-1.33)$ & 22.0 & $0.96(0.93-0.99)$ & $0.97(0.94-1.01)$ \\
\hline Delayed (17-19) & 21.7 & $2.16(1.96-2.39)$ & $1.71(1.53-1.91)$ & 24.9 & $1.13(1.12-1.14)$ & $1.06(1.06-1.08)$ \\
\hline \multicolumn{7}{|l|}{ Drug use } \\
\hline No & 10.2 & - & - & 21.5 & - & - \\
\hline Yes & 31.0 & $3.97(3.71-4.24)$ & $3.68(3.43-3.94)$ & 38.0 & $2.50(2.48-2.52)$ & $2.47(2.45-2.50)$ \\
\hline \multicolumn{7}{|l|}{ Has cellphone } \\
\hline No & 13.7 & - & - & 23.5 & - & - \\
\hline Yes & 11.1 & $0.79(0.75-0.84)$ & $0.87(0.82-0.92)$ & 22.6 & $0.95(0.95-0.96)$ & $0.95(0.95-0.96)$ \\
\hline Difficulty level & & $1.05(1.03-1.08)$ & $1.01(0.98-1.03)$ & & $1.01(1.00-1.01)$ & $0.99(0.98-0.99)$ \\
\hline \multicolumn{7}{|l|}{ School } \\
\hline Private & 8.3 & - & - & 23.9 & - & - \\
\hline Public & 12.8 & $1.62(1.52-1.73)$ & $1.57(1.46-1.68)$ & 22.4 & $0.91(0.90-0.92)$ & $0.89(0.88-0.90)$ \\
\hline \multicolumn{7}{|l|}{ Region } \\
\hline Southeast & 12.4 & - & - & 22.9 & - & - \\
\hline South & 11.5 & $0.92(0.83-1.01)$ & $0.89(0.81-0.99)$ & 23.7 & $1.01(1.01-1.02)$ & $1.03(1.02-1.03)$ \\
\hline Central & 12.5 & $1.01(0.93-1.01)$ & $1.04(0.96-1.14)$ & 22.9 & $0.99(0.98-1.00)$ & $0.99(0.98-1.00)$ \\
\hline Northeast & 11.3 & $0.89(0.84-0.96)$ & $0.96(0.89-1.03)$ & 22.0 & $0.94(0.94-0.95)$ & $0.98(0.98-0.99)$ \\
\hline North & 11.4 & $0.90(0.84-0.98)$ & $0.89(0.82-0.96)$ & 22.6 & $0.98(0.97-0.99)$ & $1.02(1.01-1.03)$ \\
\hline
\end{tabular}

95\%Cl: 95\% confidence interval; OR: odds ratio.

Being a student from a public school in 2009 was associated with a $62 \%$ increase in the odds of giving an inconsistent response to a least one item (95\%CI: 1.52-1.73), but, in 2012, this association curiously changed direction $(\mathrm{OR}=0.92$; 95\%CI: 0.89-0.95).

Self-reported level of difficulty in answering the questionnaire was not significantly associated with being inconsistent, but not having a cellphone was. In 2009, there was a $21 \%$ lower likelihood of being inconsistent among cellphone owners than among those who had none. This contrast was in the same direction but much smaller in 2012, when having a cellphone was associated with only a 5\% lower likelihood of being an inconsistent responder.

Finally, our multivariate results did not reveal strong regional differences in the odds of an inconsistent response. In both 2009 and 2012, the south and southeast regions were the ones with the highest percentages of inconsistent responders, but there were no statistically significant differences.

\section{Discussion}

The results of this study show that the majority of the participants in the PeNSE survey provided consistent reports, but that a sizable minority provided one or more self-contradictory responses. Consistent with previous analyses of other survey data, in both editions of the PeNSE survey, we found that the prevalence of inconsistency was higher for males 45,53,54,55, delayed students 56, and those who reported having experimented with drugs $26,44,56$. 
Considering that the PeNSE questionnaire is relatively long, and that the use of a smartphone could represent an extra source of difficulty for some of the participants, we tested the effect of possessing a cellphone, and also the self-reported level of difficulty in answering the questionnaire (assessed by the question: "How difficult did you find this questionnaire to answer? 1 - very easy; 2 - easy; 3 - neither difficult nor easy; 4 - difficult; 5 - very difficult). Interestingly, the self-report of difficulty was not significantly associated with being inconsistent, but not having a cellphone was. In 2009, when the percentage of Brazilian children and adolescents who had a cellphone was smaller 57 , there was a $21 \%$ lower likelihood of being inconsistent for those who had one. On the other hand, in 2012, when cellphones had become more widely available and hence familiar having a cellphone entailed a decrease of only $5 \%$ in the likelihood of being an inconsistent responder. This results suggest that familiarity with cellphone positively influence the consistency rates in both 2009 and 2012, a feature that needs to be taken into consideration in the next editions of the survey while recruiting the participants, by offering assistance to those who are not familiar with the technology.

Consistent with the literature $30,31,32,33,34,35,52,58$, inconsistency rates were higher for the most common behaviors: alcohol and cigarettes, but we found a low percentage of extreme cases of inconsistent responding, with most of the participants being flagged for inconsistency in only one of the four domains. Fewer than $4 \%$ of the participants were flagged in more than two domains, consistent with previous estimates of careless responding 59,60. This finding may suggest that, in the case of the PeNSE survey, the inconsistencies are unlikely to derive from "complete indifference or pervasive carelessness" 60,61 .

Such inconsistency was much more prevalent in 2012, especially on the question about age of first use of alcohol. Inconsistent measures of alcohol consumption can bias the estimates of morbidity, mortality, and other associated outcomes. As pointed out by Kydd 55, the validity and possible biases of self-report measures of alcohol consumption have been subjects of considerable research attention, and rates of inconsistency in this domain have been found to vary in relation to gender, ethnicity, and socioeconomic status $62,63,64$.

However, because the set of questions about alcohol was not identical in the 2009 and 2012 editions of the PeNSE survey, it is difficult to determine which factors may account for the increase in the inconsistency rate. Nonetheless, it is noteworthy that in the past years several changes were made in the Brazilian regulation for alcohol consumption, especially with the creation of the "Lei Seca" in 2008 - a dry law, different from the old American one - that makes the inspection of drivers stricter in the country, punishing people who are caught having alcohol in their blood when driving. As a consequence of the "Lei Seca", other changes were made on the alcohol regulation in Brazil, with the Law n. 5,502 from 2013 that made underage alcohol consumption illegal, as well as criminalizing the sale of alcoholic beverages to people under the age of 18 . With these changes in the federal regulation, the debate about underage drinking gained the attention of the media and became a great topic of discussion in the popular opinion, which might have indirectly affected the students' attitudes in reporting their actual drinking habits. Because underage drinking in Brazil is generally socially disapproved, we believe that this may be affecting the youths' perception of this matter and therefore causing more inconsistencies.

As there was a bigger proportion of inconsistent responses among the participants who claimed that they had "ever" engaged in three of the four types of risk behaviors, it is important to consider how reliance on these "have you ever" questions may have affected estimates of the prevalence of these behaviors among Brazilian middle school students. This prominence of inconsistent responders among the self-proclaimed risk-takers is noteworthy, because excluding those cases changes the estimates of risk behaviors for most of the domains. Most importantly, the results demonstrated that even small percentages of inconsistent responses can change the estimate of reported risk behaviors. Some of our findings replicate prior studies, which have found that excluding the cases that fail consistency checks results in a reduction in estimated rates of risk behaviors 18,44,65, but our finding that in the specific domains of alcohol use and sexual activity, the removal of inconsistent responders actually elevates estimated rates is apparently unprecedented.

Nevertheless, researchers should be cautious about removing inconsistent cases. The removal of all cases with inconsistency in any domain may increase the researcher's confidence that the reported behaviors are true behaviors, but it may also inadvertently remove valid data in domains 
where there are no inconsistencies, and thus create a bias towards more normative behavior. More generally, without further research employing methods of validation that are external to the survey itself, we simply cannot know whether the removal of data from respondents who have contradicted themselves generally tends to improve or damage the accuracy of survey-based prevalence estimates.

Our results suggest the need for more experimental studies about the assessment of risk behavior, via school-based surveys, and could be useful for the study of survey administration routines.

This study supports the importance of performing consistency checks of self-report surveys, following the growing body of literature on this topic. As suggested by Meade \& Craig 59, every survey could benefit from incorporating methods of data screening. Some of these methods entail inserting special items or scales (e.g social desirability, lie scales, bogus items) prior to the administration of survey, while others entail post hoc analysis of response patterns after the data collection. In the PeNSE survey, in particular, inconsistencies could be greatly reduced by the simple expedient of giving access to the risk behavior questions only to those participants who answer "yes" to the relevant "have you ever" question; now that the questionnaire is administered with an electronic device, this skipping over can easily be programmed.

While self-report surveys will likely continue to be an economical method for gathering risk behavior data from the students, their value is fragile, unless data quality issues are systematically addressed in administration, interpretation, reporting, and publishing of results.

\section{Contributors}

D. O. Ramos, M. Daly and P. Nadanovsky participated in the study conception, data interpretation, write-up of the article and approval of final version for publication. M. L. Seidl-de-Moura and R. T. Jomar contributed in the article write-up and approval of final version for publication.

\section{Acknowledgments}

The authors wish to thank the editorial board and reviewers for valuable contributions to the paper. We also wish to thank Brazilian Graduate Studies Coordinating Board (Capes) and Brazilian National Research Council (CNPq) for help in developing the research, including a CNPq Doctorate Bursary and Sandwich Doctorate, under reference BEX n. 99999.010112/2014-06.

\section{References}

1. Brener ND, Billy JO, Grady WR. Assessment of factors affecting the validity of self-reported health-risk behavior among adolescents: evidence from the scientific literature. J Adolesc Health 2003; 33:436-57.

2. Instituto Brasileiro de Geografia e Estatística. Pesquisa Nacional de Saúde do Escolar (PeNSE), 2009. Brasília: Instituto Brasileiro de Geografia e Estatística; 2009.

3. Instituto Brasileiro de Geografia e Estatística. Pesquisa Nacional de Saúde do Escolar (PeNSE), 2012. Brasília: Instituto Brasileiro de Geografia e Estatística; 2012.

4. Araújo C, Toral N, Silva ACF, Velásquez-Melendez G, Dias AJR. Estado nutricional dos adolescentes e sua relação com variáveis sociodemográficas: Pesquisa Nacional de Saúde do Escolar (PeNSE), 2009. Ciênc Saúde Coletiva 2010; 15 Suppl 2:3077-84.

5. Freire MCM, Leles CR, Sardinha LMV, Paludetto Junior M, Malta DC, Peres MA. Dor dentária e fatores associados em adolescentes brasileiros: a Pesquisa Nacional de Saúde do Escolar (PeNSE), Brasil, 2009. Cad Saúde Pública 2012; 28 Suppl:S133-45.

6. Horta RL, Horta BL, Costa AWN, Prado RR, Oliveira-Campos M, Malta DC. Lifetime use of illicit drugs and associated factors among Brazilian schoolchildren, National Adolescent School-based Health Survey (PeNSE 2012). Rev Bras Epidemiol 2014; 17 Suppl 1:31-45.

7. Malta DC, Andreazzi MAR, Oliveira-Campos M, Andrade SSCA, Sá NNB, Moura L, et al. Trend of the risk and protective factors of chronic diseases in adolescents, National Adolescent School-based Health Survey (PeNSE 2009 and 2012). Rev Bras Epidemiol 2014; 17 Suppl 1:77-91. 
8. Malta DC, Oliveira-Campos M, Prado RR, Andrade SSC, Mello FCM, Dias AJR, et al. Psychoactive substance use, family context and mental health among Brazilian adolescents, National Adolescent School-based Health Survey (PeNSE 2012). Rev Bras Epidemiol 2014; 17 Suppl 1:46-61.

9. Malta DC, Sardinha LMV, Mendes I, Barreto SM, Giatti L, Castro IRR, et al. Prevalence of risk health behavior among adolescents: results from the 2009 National Adolescent School-based Health Survey (PeNSE). Ciênc Saúde Coletiva 2010; 15 Suppl 2:3009-19.

10. Malta DC, Machado IE, Porto DL, da Silva MMA, de Freitas PC, da Costa AWN, et al. Alcohol consumption among Brazilian Adolescents according to the National Adolescent School-based Health Survey (PeNSE 2012). Rev Bras Epidemiol 2014; 17 Suppl 1:203-14.

11. Morais Neto OL, Malta DC, Mascarenhas MDM, Duarte EC, Silva MMA, Oliveira KB, et al. Risk factors for road traffic injury among adolescents in Brazil: National Adolescent School-based Health Survey (PeNSE). Ciênc Saúde Coletiva 2010; 15 Suppl 2:3043-52.

12. Oliveira-Campos M, Nunes ML, Madeira FC, Santos MG, Bregmann SR, Malta DC, et al. Sexual behavior among Brazilian adolescents, National Adolescent School-based Health Survey (PeNSE 2012). Rev Bras Epidemiol 2014; 17 Suppl 1:116-30.

13. Malta DC, Mascarenhas MDM, Porto DL, Duarte EA, Sardinha LM, Barreto SM, et al. Prevalência do consumo de álcool e drogas entre adolescentes: análise dos dados da Pesquisa Nacional de Saúde Escolar. Rev Bras Epidemiol 2011; 14 Suppl 1:136-46.

14. Malta DC, Porto DL, Melo FCM. Família e proteção ao uso de tabaco, álcool e drogas em adolescentes, Pesquisa Nacional. Rev Bras Epidemiol 2011; 14 Suppl 1:166-77.

15. Malta DC, Silva MAI, Mello FCM, Monteiro RA, Porto DL, Sardinha LMV, et al. Saúde sexual dos adolescentes segundo a Pesquisa $\mathrm{Na}$ cional de Saúde dos Escolares. Rev Bras Epidemiol 2011; 14 Suppl 1:147-56.

16. Barreto SM, Giatti L, Oliveira-Campos M, Andreazzi MA, Malta DC. Experimentation and use of cigarette and other tobacco products among adolescents in the Brazilian state capitals (PeNSE 2012). Rev Bras Epidemiol 2014; 17 Suppl 1:62-76.

17. Cross JE, Newman-Gonchar R. Data quality in student risk behavior surveys and administrator training. J Sch Violence 2004; 3:89-108.

18. Cornell DG, Loper AB. Assessment of violence and other high-risk behaviors with a school survey. School Psych Rev 1998; 27:317-30.

19. Tavares LF, Castro IRR, Levy RB, Cardoso LO, Passos MD, Brito FSB. Validade relativa de indicadores de práticas alimentares da Pesquisa Nacional de Saúde do Escolar entre adolescentes do Rio de Janeiro, Brasil. Cad Saúde Pública $2014 ; 30: 1029-41$.
20. Tavares LF, Castro IR, Cardoso LO, Levy RB, Claro RM, Oliveira AF. Validade de indicadores de atividade física e comportamento sedentário da Pesquisa Nacional de Saúde do Escolar entre adolescentes do Rio de Janeiro, Brasil. Cad Saúde Pública 2014; 30:1861-74.

21. Midanik L. The validity of self-reported alcohol consumption and alcohol problems: a literature review. Br J Addict 1982; 77:357-82.

22. Rodgers JL, Billy JO, Udry JR. The rescission of behaviors: inconsistent responses in adolescent sexuality data. Soc Sci Res 1982; 11:280-96.

23. Hilton ME. Inconsistent responses to questions about alcohol consumption in specified settings. Am J Drug Alcohol Abuse 1986; 12:403-13.

24. Friedenreich CM. Improving long-term recall in epidemiologic studies. Epidemiology 1994; 5:1-4.

25. Barnea Z, Rahav G, Teichman M. The reliability and consistency of self-reports on substance use in a longitudinal study. Br J Addict 1987; 82:891-8.

26. Palen L-A, Smith EA, Caldwell LL, Flisher AJ, Wegner L, Vergnani T. Inconsistent reports of sexual intercourse among South African high school students. J Adolesc Health 2008; 42:221-7.

27. Dolcini MM, Adler NE, Ginsberg D. Factors influencing agreement between self-reports and biological measures of smoking among adolescents. J Res Adolesc 1996; 6:515-42.

28. Matsushima R, Shiomi K. Social self-efficacy and interpersonal stress in adolescence. Soc Behav Pers 2003; 31:323-32.

29. van de Mortel TF. Faking it: social desirability response bias in self-report research. Aust J Adv Nurs 2008; 25:40-8.

30. Blair E, Burton S. Cognitive processes used by survey respondents to answer behavioral frequency questions. J Consum Res 1987; 14:280-8.

31. Menon G. The effects of accessibility of information in memory on judgments of behavioral frequencies. J Consum Res 1993; 20: 431-40.

32. Stone AA, Bachrach CA, Jobe JB, Kurtzman HS, Cain VS, editors. The science of self-report: Implications for research and practice. New Jersey: Lawrence Erlbaum; 2000.

33. Menon G. Judgments of behavioral frequencies: memory search and retrieval strategies. In: Schwarz N, Sudman S, editors. Autobiographical memory and the validity of retrospective reports. New York: Springer; 1994. p. 161-72.

34. Menon G, Raghubir P, Schwarz N. Behavioral frequency judgments: an accessibilitydiagnosticity framework. J Consum Res 1995; 22:212-28.

35. Menon G, Yorkston EA. The use of memory and contextual cues in the formation of behavioral frequency judgments. In: Stone AA, Bachrach CA, Jobe JB, Kurtzman HS, Cain VS, editors. The science of self-report: implications for research and practice. New Jersey: Lawrence Erlbaum; 2000. p. 63-79. 
36. Willis GB. Cognitive interviewing: a tool for improving questionnaire design. Thousand Oaks: Sage Publications; 2004.

37. Appel PW, Hoffman JH, Blane HT, Frank B, Oldak R, Burke M. Comparison of self-report and hair analysis in detecting cocaine use in a homeless/transient sample. J Psychoactive Drugs 2001; 33:47-55.

38. Colón HM, Robles RR, Sahai H. The validity of drug use responses in a household survey in Puerto Rico: comparison of survey responses of cocaine and heroin use with hair tests. Int J Epidemiol 2001; 30:1042-9.

39. Colón HM, Robles RR, Sahai H. The validity of drug use self-reports among hard core drug users in a household survey in Puerto Rico: comparison of survey responses of cocaine and heroin use with hair tests. Drug Alcohol Depend 2002; 67:269-79.

40. Fendrich M. The undeniable problem of recanting. Addiction 2005; 100:143-4.

41. Fendrich M, Johnson TP, Sudman S, Wislar JS, Spiehler V. Validity of drug use reporting in a high-risk community sample: a comparison of cocaine and heroin survey reports with hair tests. Am J Epidemiol 1999; 149:955-62.

42. Fendrich M, Rosenbaum DP. Recanting of substance use reports in a longitudinal prevention study. Drug Alcohol Depend 2003; 70:241-53.

43. Johnson TP, Mott JA. The reliability of selfreported age of onset of tobacco, alcohol and illicit drug use. Addiction 2001; 96:1187-98.

44. Miller P, Curtis A, Jenkinson R, Droste N, Bowe SJ, Pennay A. Drug use in Australian nightlife settings: estimation of prevalence and validity of self-report. Addiction 2015; 110:1803-10.

45. Tassiopoulos K, Bernstein J, Heeren T, Levenson S, Hingson R, Bernstein E. Predictors of disclosure of continued cocaine use. Addict Behav 2006; 31:80-9.

46. Currie C, Nic Gabhainn S, Godeau E; International HBSC Network Coordinating Committee. The health behaviour in school-aged children WHO Collaborative Cross-National (HBSC) Study: origins, concept, history and development 1982-2008. Int J Public Health 2009; 54 Suppl 2:131-9.

47. Ministério da Educação. Ensino Fundamental de nove anos: perguntas mais frequentes e respostas da Secretaria de Educação Básica (SEB/ MEC). portal.mec.gov.br/seb/arquivos/pdf/ Ensfund/ensfund9_perfreq.pdf (accessed on 01/Aug/2015).

48. Reis JGA, Barros R. Desigualdade salarial e distribuição de educação: a evolução das diferenças regionais no Brasil. Pesquisa e Planejamento Econômico 1990; 20:415-78.

49. Medeiros M, Oliveira LFB. Desigualdades regionais em educação: potencial de convergência. Soc Estado 2014; 29:561-85.

50. Picanço MRA. A idade da menarca da menina brasileira: os fatores socieconômicos e as diferenças regionais. Análise dos dados da PNSN, 1989 [Doctoral Dissertation]. Rio de Janeiro: Instituto Fernandes Figueira, Fundação Oswaldo Cruz; 1995.
51. Heilborn ML. O aprendizado da sexualidade: reprodução e trajetórias sociais de jovens brasileiros. Rio de Janeiro: Editora Garamond/ Editora Fiocruz; 2006.

52. Pinsky I, Zaleski M, Laranjeira R, Caetano R. First national survey on patterns of alcohol consumption in the Brazilian population. Rev Bras Psiquiatr 2010; 32:214-5.

53. Cornell DG, Lovegrove PJ, Baly MW. Invalid survey response patterns among middle school students. Psychol Assess 2014; 26:277-87.

54. Maniaci MR, Rogge RD. Caring about carelessness: participant inattention and its effects on research. J Res Pers 2014; 48:61-83.

55. Kydd RM, Connor J. Inconsistency in reporting abstention and heavy drinking frequency: associations with sex and socioeconomic status, and potential impacts. Alcohol Alcohol 2015; 50:33-45.

56. Harris KM, Griffin BA, McCaffrey DF, Morral AR. Inconsistencies in self-reported drug use by adolescents in substance abuse treatment: implications for outcome and performance measurements. J Subst Abuse Treat 2008; 34:347-55

57. Cunha P. Adolescentes lideram aumento de uso de celular no Brasil diz Pnad. http://g1. globo.com/tecnologia/noticia/2012/09/ado lescentes-lideram-aumento-de-uso-de-celu lar-no-brasil-diz-pnad.html (accessed on 01/ Aug/2015).

58. Burton S, Blair E. Task conditions, response formulation processes, and response accuracy for behavioral frequency questions in surveys. Public Opin Q 1991; 55:50-79.

59. Meade AW, Craig SB. Identifying careless responses in survey data. Psychol Methods 2012; 17:437-55

60. Johnson JA. Ascertaining the validity of individual protocols from web-based personality inventories. J Res Pers 2005; 39:103-29.

61. Baer RA, Ballenger J, Berry DT, Wetter MW. Detection of random responding on the MMPI-A. J Pers Assess 1997; 68:139-51.

62. Berry DT, Wetter MW, Baer RA, Larsen L, Clark C, Monroe K. MMPI-2 random responding indices: validation using a self-report methodology. Psychol Assess 1992; 4:340-5.

63. Midanik LT, Greenfield TK. Defining "current drinkers" in national surveys: results of the 2000 National Alcohol Survey. Addiction 2003; 98:517-22.

64. Greenfield TK, Kerr WC. Alcohol measurement methodology in epidemiology: recent advances and opportunities. Addiction 2008; 103:1082-99.

65. Rosenblatt JA, Furlong MJ. Assessing the reliability and validity of student self-reports of campus violence. J Youth Adolesc 1997; 26:187-202. 


\section{Resumo}

O presente estudo avaliou as inconsistências no autorrelato de comportamentos de risco (geral e em quatro domínios específicos: uso de álcool, tabaco, drogas e atividade sexual) em duas edições da Pesquisa Nacional de Saúde do Adolescente (PeNSE): 2009 e 2012. Nas duas edições, a proporção de casos com ao menos uma resposta inconsistente foi de 11,7\% (2,7\% nos itens sobre consumo de álcool, 2,1\% para uso de drogas, 4,3\% para uso de tabaco, 3\% para atividade sexual) e 22,7\% (12,8\% nos itens sobre consumo de álcool, 2,5\% para uso de drogas, 4,3\% para uso de tabaco, 4,1\% para atividade sexual), respectivamente. Tal inconsistência foi mais prevalente entre participantes do sexo masculino, estudantes com atraso escolar, participantes que relataram ter experimentado drogas e participantes que não possuíam telefone celular. Dado que as inconsistências foram mais prevalentes entre os estudantes que declararam ter se engajado nos comportamentos de risco, remover os casos com inconsistência afetou as estimativas de prevalência destes comportamentos em ambas as edições da pesquisa. Este estudo ressalta a importância de testes para a checagem da consistência dos dados autorrelato em pesquisas, acompanhando a crescente literatura na área.

Assunção de Riscos; Autorrelato; Inquéritos; Metodologia; Adolescente

\section{Resumen}

Este estudio evaluó las inconsistencias en las conductas de riesgo de auto-reporte (general y cuatro áreas específicas: el alcohol, el tabaco, las drogas y la actividad sexual) en dos ediciones de la Encuesta Nacional de Salud del Adolescente (PeNSE): 2009 y 2012. En dos ediciones, la proporción de casos con al menos una respuesta inconsistente fue $11,7 \%$ (2,7\% en alcohol, 2, 1\% en drogas, 4,3\% en tabaco, $3 \%$ en actividad sexual) y 22,7\% (12,8\% en alcohol, 2,5\% en drogas, 4,3\% en tabaco, 4, 1\% en actividad sexual), respectivamente. Tal inconsistencia era más frecuente entre los participantes masculinos, los alumnos con retraso escolar, los participantes que reportaron haber consumido drogas y participantes probado que no tenían teléfono celular. Dado que las inconsistencias fueron más prevalentes entre los estudiantes que reportaron haber participado en comportamientos de riesgo, eliminar los casos de inconsistencia afectó a las estimaciones de la prevalencia de estas conductas en las dos ediciones de la encuesta. Este estudio pone de relieve la importancia de las pruebas para comprobar la coherencia de los datos de auto-informe sobre la investigación, a raíz de la creciente literatura en la zona.

Asunción de Riesgos; Autoinforme; Encuestas; Metodología; Adolescente
Submitted on $04 / \mathrm{Sep} / 2015$

Final version resubmitted on $06 / \mathrm{Jun} / 2016$

Approved on 13/Jun/2016 